\title{
Justification and False Belief: Gettier's First Point
}

\section{Michael Perrick}

Retired, Berg en Dal, The Netherlands

Email: m.perrick@kpnmail.nl

How to cite this paper: Perrick, M. (2016). Justification and False Belief: Gettier's First Point. Open Journal of Philosophy, 6, 446454.

http://dx.doi.org/10.4236/ojpp.2016.64042

Received: October 14, 2016

Accepted: November 14, 2016

Published: November 17, 2016

Copyright $\odot 2016$ by author and Scientific Research Publishing Inc. This work is licensed under the Creative Commons Attribution International License (CC BY 4.0).

http://creativecommons.org/licenses/by/4.0/

\begin{abstract}
Appearances notwithstanding, in this paper we do not discuss the Gettier problem. The question at issue is whether one can be justified in believing a false proposition. So, what is at stake is the relation between justified belief and falseness. In his famous paper, Gettier presupposes explicitly that one can be justified in believing a false proposition (Gettier's "first point"). He makes essential use of this point in arguing for his well-known Gettier cases. I will prove that this point, in Gettier's robust reading, is untenable since it leads to incompatible or contradictory consequences. It is only in a much weaker sense than we find in Gettier's paper that it seems possible to be justified in believing a false proposition.
\end{abstract}

\section{Keywords}

False Belief, Gettier

\section{Introduction}

There seems to be wide agreement that one can be justified in believing a false proposition. On the one hand, this might seem quite curious. Since we usually consider believing a proposition as taking that proposition for true, we seem to verge on contradiction when we, carelessly, take justified false belief just for granted. On the other hand, the history of science confronts us with theories that we once held on very solid grounds but later had to give up.

In respect of justified false belief, we should distinguish, so I argue, between a conjunctive and a non-conjunctive reading. In a conjunctive reading, we have a conjunction-in the truth-functional sense-of $\mathrm{p}$ as a justifiably believed proposition and (the same) $\mathrm{p}$ as a false one.

In the non-conjunctive ("successive") reading this is not the case; this latter seems rather unproblematic but incapable of doing justice to what we in some circumstances seem to understand by a justified false belief. 
As for the conjunctive reading, we further need a distinction between a first person standpoint ("I-or we-believe falsely", rejected by Wittgenstein), and a third person standpoint. This third person standpoint of the conjunctive reading of a justified false belief is precisely what Gettier, in his classic, introduces with his "first point". This first point boils down to the supposed fact that we can attribute to somebody else a belief both justified and false, and plays an essential role in Gettier's arguments. It is, therefore, from Gettier's arguments, by proving that Gettier's first point is inconsistent, that I will make clear that one cannot be justified in believing a false proposition, except in a rather weak sense (i.e. the non-conjunctive reading).

\section{Justification and False Belief: The Problem}

In Gettier's classic, the supposed platitude that one can be justified in believing a false proposition-where the history of science seems to bear ample evidence of-gets a precise interpretation.

In order to reach his famous conclusion (justified true belief is insufficient for knowledge), Gettier drives a wedge between the reasons why propositions are true, and why they are justified. This comes clearly to the fore especially in the first of two points that Gettier proposes. Both points are of fundamental importance to his argument.

"First, in that sense of 'justified' in which S's being justified in believing $P$ is a necessary condition of $S$ 's knowing that $P$, it is possible for a person to be justified in believing a proposition that is in fact false. Second, for any proposition $P$, if $\mathrm{S}$ is justified in believing $P$ and $P$ entails $\mathrm{Q}$, and $\mathrm{S}$ deduces $\mathrm{Q}$ from $P$ and accepts $\mathrm{Q}$ as a result of this deduction, then $S$ is justified in believing Q." (Gettier, 1963: p. 121).

Gettier's second point gives his principle of deduction for justified belief. I take this for granted. Unless we deny the possibility of deriving a justified belief from another one, or knowledge from knowledge, we will have to accept a principle like Gettier's second point.

According to Gettier's first point, it may happen that someone is justified in believing a proposition that is in fact false. It is this first point that I will call into question.

Assuming that to believe a proposition, $p$, means to take $p$ to be true, it seems impossible that for somebody, $\mathrm{S}$, the falseness of $\mathrm{p}$ lies within the scope of the belief clause.

Since Gettier takes his first point as something actual rather than possible, I leave out his possibility clause and take his first point as a conjunction, $\mathrm{A}$, in the truth-functional sense:

A: [(S is justified in believing proposition p.) \& (p is false.) $]^{1}$

This conjunction A makes it impossible to read Gettier's first point as a case in which Gettier's dramatis persona, Smith, S, justifiably takes a proposition to be both true and false. Since in A the falseness of $p$ lies explicitly outside the scope of the belief clause, such a contradictory reading is excluded. However, it is far from clear whether S can subscribe to conjunction A. Can S himself accept both conjuncts of A together?

Gettier clearly suggests, in both his cases (Gettier, 1963: pp. 122-123), that S is un-

${ }^{1}$ Both conjuncts figure explicitly as premises in Gettier's two cases. 
aware of the (justified) proposition being false; this points to a negative answer and the reason why is evident.

Given that $S$ has very good reasons for taking $p$ to be true, $S$ cannot-at the same time-assume that $\mathrm{p}$ is false, and vice versa. So, at least for $\mathrm{S}$, both conjuncts seem incompatible. Suppose that $S$ justifiably believes $p$. This is no sufficient reason for holding that $\mathrm{p}$ cannot be false, but it suffices for denying that $\mathrm{S}$ himself can accept both conjuncts of A, i.e. endorse A.

Let us call the point of view from which we ask whether S himself can subscribe to A the first person standpoint. Considered from this first person standpoint, Gettier's first point, conjunction A, is inconsistent. (This is not to suggest that Gettier himself in any way subscribes to what $I$ call here the first person standpoint of Gettier's first point.)

As Wittgenstein put it: "If there were a verb meaning 'to believe falsely', it would not have a meaningful first person present indicative." (Wittgenstein, 1953: p. 190. Compare Macarthur below. $)^{2}$

Intuitively speaking, however, it still seems quite possible that $S$ has very good reasons for believing $\mathrm{p}$, although $\mathrm{p}$ is false.

Suppose that we know (or, with Gettier, assume) that $\mathrm{p}$ is false. From this third person standpoint, then, we assert that $\mathrm{p}$, the proposition $\mathrm{S}$ justifiably believes, is false. Do we here, then, have a case in which $\mathrm{p}$ is both justified and false?

Knowing $\mathrm{p}$ to be false, we seem to have here, from our third person standpoint, a gut feeling that $\mathrm{p}$ is both justified and false, and, therefore, that conjunction $\mathrm{A}$ is true. For, although we know that $\mathrm{p}$ is false, we may acknowledge that $\mathrm{S}$ has, from $\mathrm{S}$ 's own point of view, very good reasons for believing $p$. Therefore, we can attribute to $S$ that $S$ is justified in believing the false proposition p. (It is also in the sense of conjunction A that we might say in respect of a venerable theory from the past that its adherents were quite justified in holding it although it was false.) But we cannot, of course, ourselves subscribe to S's reasons for believing $\mathrm{p}$, since, from our third person standpoint, we know $\mathrm{p}$ to be false.

Macarthur describes the predicament as follows:

"To believe that $\mathrm{P}$ is, at a minimum, to be committed to the truth of $\mathrm{P}$. It is to take $\mathrm{P}$ to be true. But we also know from past mistakes in judgment and the ever-present fact of disagreement with others that it is possible to believe what is, in fact, not true. So we are aware that taking-true is distinguishable from truth even though in the first-person present there is no such distinction to be drawn." (Macarthur, 2004: p. 122).

In the "first person present (indicative)", the conjunctive reading of (justified) false belief seems irrevocably contradictory: "I-or we-believe falsely (take to be true falsely)..." Therefore, Wittgenstein and Macarthur deny that for the first person present any (justified) belief in a false proposition is possible.

In the sequel, I will prove that-even considered from a third person standpointconjunction A, Gettier's first point, is untenable, since it leads to incompatible or con-

\footnotetext{
${ }^{2}$ The reference to this text I owe to Barry Stroud. (Stroud, 2011: motto).
} 
tradictory consequences.

But first I will discuss the non-conjunctive reading, by answering the following question: how to explain our widespread conviction that one can justifiably believe a false proposition?

By taking Gettier's first point as conjunction A, I am not denying that we can-and often do-correctly speak of a (justifiably) believed but false proposition in a much weaker sense.

This is not to say that the notions justified belief and falseness themselves are weaker here (they are the same); but the fact that they are not applicable at the same time, at once, is the reason why I speak here of a weaker sense of a justifiably believed but false proposition.

Legalistically, one could speak here perhaps of a misnomer since the notions justifiably believed and false are not conjunctively applied to a proposition $\mathrm{p}$, but rather "successively". I guess we are all familiar with a case in which one had good reasons for believing a proposition $\mathrm{p}$ that afterwards proved to be false. In such a case, however, there is no conjunction (in the truth-functional sense) of $\mathrm{p}$ as a justifiably believed proposition and $\mathrm{p}$ as a false proposition. For, as long as one (justifiably) believes $\mathrm{p}$, one does not take $\mathrm{p}$ to be false, and as soon as one assumes that $\mathrm{p}$ is false, one no longer believes p. (Compare Henry's case below.) Here, too, we should hold that the falseness of $p$ lies outside the scope of the belief clause, on penalty of contradiction. It is from this (rather weak) non-conjunctive reading that the plausibility or acceptability of justifiably believed but false propositions seems to derive. In this non-conjunctive reading, there is no need to distinguish between a first and a third person standpoint. Today I can have very good reasons for believing a proposition that tomorrow I might have to give up. If this non-conjunctive reading were all there is to the notion justified false belief, matters would seem to be rather unproblematic.

Both Gettier cases-to be discussed below-could illustrate this point. For in either case it seems quite reasonable to suppose that $S$ would give up his justified belief when confronted with its falseness.

On this weak interpretation, however, no construction of Gettier cases seems possible, and that is why Gettier endorses the conjunctive reading.

Although Gettier explicitly uses both conjuncts of A as premises in both his cases, Gettier's arguments do not result in incompatible or contradictory conclusions.

To prove, nevertheless, that Gettier's first point, conjunction A, is inconsistent, I shall make use of Gettier's own premises and assumptions, and deduce two incompatible propositions in both Gettier's cases, as alternative conclusions.

In my conclusion, I shall generalize this procedure.

So what is at stake hereafter is the conjunctive reading of justified false belief from the third person standpoint, or, Gettier's first point, conjunction A. This turns out to be the supposed fact that we can attribute to somebody else a belief both justified and false.

In his two cases, Gettier adduces substitution instances of both conjuncts of conjunction $\mathrm{A}$ as premises in his argument. 


\section{Gettier's Case I}

In Case I, Gettier starts with the following premise:

(d) Jones is the man who will get the job, and Jones has ten coins in his pocket.

Proposition (d) entails:

(e) The man who will get the job has ten coins in his pocket.

Assuming that Smith, S, is justified in believing (d), it follows, by virtue of Gettier's second point, his deduction principle, that $S$ is also justified in believing (e).

The next step in Gettier's argument is the assumption that (d) is false. Not Jones, but, unknown to Smith, Smith himself, S, will get the job, and, also, S happens to have ten coins in his pocket. Thus it is assumed that $S$ is justified in believing a proposition, (d), which is false. We assert, from our third person standpoint, that what $\mathrm{S}$ believes, (d), is false. S himself takes (d), like all Gettier's sample sentences, to be true.

I shall prove now that we can deduce a contradiction from S's justified belief in (d), which is false, and Gettier's deduction principle, his second point. (It is also from a justifiably believed but false proposition and his deduction principle that Gettier derives his so-called Gettier cases.) Consider the following propositions:

(d1) $\mathrm{S}$ is justified in believing that Jones is the man who will get the job, and that Jones has ten coins in his pocket.

(e1) $\mathrm{S}$ is justified in believing that the man who will get the job has ten coins in his pocket.

Gettier endorses both (d1) and (e1).

Proposition (d1) expresses the fact that $\mathrm{S}$ is justified in believing (d), and proposition (e1) that he is justified in believing (e). Proposition (e), unlike (d), is true.

Further, both (d1) and (e1) correctly express the fact that $\mathrm{S}$ has a justified belief and are, therefore, true. The propositions (d) and (e) are what $\mathrm{S}$ is justified in believing, according to respectively (d1) and (e1).

Although (e1) is a valid consequence of (d1), given Gettier's second point, what we attribute to $\mathrm{S}$ as justifiably believing according to (d1) - i.e. (d) - is at odds with what we attribute to $S$ as justifiably believing according to (e1), i.e. (e).

Since (d) is false, what we attribute to $S$ as justifiably believing according to (d1), i.e. (d), is false. On the other hand, since what we attribute to $\mathrm{S}$ as justifiably believing according to (e1)-i.e. (e) - is true, and, since, again, (d) is false, it follows that the man concerning whom we attribute to $S$ a justified belief according to (e1) cannot be Jones. (Unless, of course, we want to attribute to $S$ that $S$ justifiably believes that Jones both gets and does not get the job.)

As we saw, Gettier subscribes to both (d1) and (e1).

According to (d1), we have to attribute to $S$ that he is justified in believing that Jones will get the job. According to (e1), and, again, given the falseness of (d) and the truth of (e), we have to attribute to $S$ that he is justified in believing that not Jones but another man will get the job. Thus we see that accepting Gettier's premises results in a contradiction, in respect of what we should attribute to $S$ as justifiably believing, to wit, two incompatible propositions, (d) and (e), one true, the other false. Needless to say that $S$ 
himself is unaware of this contradiction (since $\mathrm{S}$ takes all Gettier's sample sentences to be true), precisely as $S$ is unaware of the Gettier cases Gettier attributes to $S$.

Suppose one demands that it be proved that the contradiction or inconsistency here is "formal" and not just "material". One easily sees that making such a demand on what is believed ipso facto entails a downgrading of the believer. For, what we are engaged in here are contexts of (justified) belief. Therefore, if we demand that $S$ (justifiably!) believe a proposition, explicitly of the form "p \& non-p", we degrade $S$ to a moron.

\section{Gettier's Case II}

In Case II, Smith has strong evidence for proposition (f):

(f) Jones owns a Ford.

I take this to mean that $S$ is justified in believing (f). Proposition (f) entails:

(h) Either Jones owns a Ford, or Brown is in Barcelona.

Since $S$ is justified in believing ( $f$ ), it follows, by virtue of Gettier's second point, that $S$ is also justified in believing (h). (S has no idea where Brown actually is.) Suppose that $S$ further deduces from (f) proposition (k):

(k) Either Jones owns a Ford, or Brown is not in Barcelona ${ }^{3}$.

Clearly, (k) is entailed by (f); moreover, since $S$ is justified in believing (f), it follows-again by virtue of Gettier's second point—that $S$ is also justified in believing $(\mathrm{k})$.

Gettier's next step is the assumption that ( $\mathrm{f}$ ) is false and that Brown actually is in Barcelona. It follows that $(\mathrm{h})$ is true and that $(\mathrm{k})$ is false. Nevertheless, we can still attribute to $S$ that he is justified in believing both (h) and (k), since $S$ 's belief in (f) is still justified. That (f) is false does not detract from (f)'s being justified, according to Gettier.

Although their second disjuncts are contradictorily opposed, $(\mathrm{h})$ and $(\mathrm{k})$ can be quite compatible; but since, moreover, (f), their first disjunct, proves to be false, it follows that one of both propositions is true, the other false. Both propositions contradict each other.

Again we can attribute to $S$ that $S$ justifiably believes two incompatible propositions.

\section{Conclusion}

It is not difficult to see that the way I handle Gettier's Case II can easily be generalized, i.e. can be equally applied to any case in which someone is supposed to be justified in believing a false proposition. (Except in the weak sense of the non-conjunctive reading.)

This includes Case I. Given that S is justified in believing (d), and that (d) entails both [(d) or (n)] and [(d) or not (n)]. From this we can deduce, by virtue of Gettier's second point, that $S$ justifiably believes the propositions [(d) or (n)] and [(d) or not (n)].

Since 1) what we attribute to $S$ as justifiably believing, (d), the first disjunct of both propositions, is false, and since 2) their second disjuncts are contradictorily opposed, it follows that one of both propositions must be true, the other false; both propositions contradict each other.

${ }^{3}$ This is not one of Gettier's sample sentences; rather, it epitomizes some of them. 
Again we can attribute to $S$ that $S$ is justified in believing two incompatible propositions.

To obviate the occurrence of these incompatibilities, one might deny the validity of Gettier's deduction principle, or, more generally, deny that an epistemic property (like being justified) is transferable under logical deduction ${ }^{4}$. But, if we want to preserve in our derivational methods truth and epistemic status, like being justified, and be able to deduce knowledge from knowledge, we will have to rely on logical deduction as the vehicle to transfer these matters.

With this proviso, then, I think to have proved that the assumption that someone has a justified belief in a false proposition leads easily to incompatibilities ${ }^{5}$. Harbouring contradictory beliefs is one thing, perhaps unavoidable. Deliberately accepting premises from which we can deduce-ad libitum-contradictory propositions is something quite different. After I earlier-in par. 2.- turned down the demand for a proof of "formal" instead of "material" inconsistency in belief contexts, I think I have proved the maximally attainable:

Every time it is claimed that someone is justified in believing a false proposition, it is possible to produce an alternative conclusion by deducing any two propositions, $\mathrm{p}$ and $\mathrm{q}$, that fulfil the following conditions: $\mathrm{p}$ and $\mathrm{q}$ contradict each other, and both can be ascribed to the believer.

Both in Gettier's argument and in my counterargument, the point is not what S actually believes, but what we can attribute to $\mathrm{S}$ as believing. (What $\mathrm{S}$ actually believes is simply this:

Gettier's sample sentences, and, by implication, my sample (k)).

Although Gettier's arguments themselves do, indeed, not lead to contradictory results, Gettier's first point is inconsistent, since it enables us-in both cases-to attribute to $S$ a justified belief in two incompatible propositions. Ex falso sequitur quodlibet. Further, assuming Wittgenstein and Macarthur to be right, it seems impossible to construct a Gettier case on the basis of the first person present indicative.

\section{Final Remarks}

Suppose we can construct Gettier-like cases without appealing to Gettier's first point, as some have suggested. Take, for instance, the following consideration:

"Henry drives through the countryside, sees a barn in the field to the right and forms a true belief that he is facing a barn. Unbeknownst to Henry, he is looking at the only real barn in a field otherwise full of barn facades that are so cleverly constructed as to be indistinguishable by the naked eye from real barns. Henry's belief is justified and true but it does not qualify as knowledge. Notice that, crucially, Henry need form no false beliefs at all here. So, even if we were to grant that it is impossible to have justified false beliefs (somewhat implausibly as it would commit us to holding that were Henry to look at a perfect fake his corresponding belief would not be justified), Gettier's argu-

${ }^{4}$ For references to some proposals to this purpose, cf. Kitcher in Kitcher (1992: p. 60).

${ }^{5}$ If one objects that the contradictions in the above are only attributed to $\mathrm{S}$ and that they don't matter since $\mathrm{S}$ is unaware of them, my reply is that exactly the same point applies to Gettier's own cases. 
ment would still go through." 6 .

In Henry's case, two theses are put forward. 1) Without an appeal to Gettier's first point, Gettier cases can be constructed. 2) Moreover, it still seems possible to have a justified false belief.

Some short comments:

1. My subject is not the Gettier problem, but Gettier's first point.

2. If Henry's supposedly justified true belief concerning the (only) barn does not rank as knowledge, this is due to the artificial aspects of the case. Without these aspects, Henry's supposedly justified true belief most probably would count as knowledge. But with these aspects, how could Henry's true belief be justified?

For, these very same aspects are a denial of what is "normal". Normally, what looks like a barn is a barn. Laying down these artificial aspects results in this negative statement:

With one exception, everything that looks like a barn is no barn but a barn facade.

The truth of this negative statement is presupposed ${ }^{7}$ and makes it quite doubtful that Henry's true belief is justified, even when he faces the only real barn, let alone that Henry - as is suggested - would still be justified in believing to face a barn when he sees a barn facade.

For it would be very questionable whether in these artificial circumstances we could appeal to something like what Audi calls the perceptual principle:

"If $S$ has a clear sensory impression of $\mathrm{x}$ 's being $\mathrm{F}$ (or that $\mathrm{x}$ is $\mathrm{F}$ ) and on the basis of that impression believes that $\mathrm{x}$ is $\mathrm{F}$, then this belief is (prima facie) justified." (Audi, 2000: p. 329) $)^{8}$.

3. Leaving this last point aside, just assume that Henry's belief that he faces a barn when seeing a barn facade is justified. Since Gettier's assumption of a belief both justified and false is supposedly redundant, we are confronted here with a case of justified false belief in the weak or non-conjunctive sense. As soon as Henry gets better informed (gets a better look) he will give up his belief that he is facing a barn, instead of a barn facade. Such a case is quite innocent; it could not contribute to the construction of a Gettier case.

How interesting these considerations may be for the Gettier problem, they are irrelevant to the subject here discussed. For, we would still be stuck with a major problem since Gettier's first point stands for our gut feeling that one can be justified in believing a false proposition, in the sense that we can attribute to somebody else a belief both justified and false. This point seems highly relevant to the history of science and to epistemology, but turns out to be untenable. The weak interpretation of justified false belief (the non-conjunctive, "successive", reading) probably does no justice to this gut feeling. But to expect more seems unwarranted.

\footnotetext{
${ }^{6}$ Variants of the Henry sees a barn (facade) example are used by several philosophers to different purposes. See, for instance, Kripke in Kripke (2011: p. 165ff). The quoted variant I owe to an anonymous referee.

${ }^{7}$ According to Shope, the presupposition of a false statement is an essential condition for any Gettier case. Cf. Shope, in Shope (1983, passim).

${ }^{8}$ Audi presents this principle with due caveats. Cf. also Lehrer, in Lehrer (2000: pp. 151-175) on (undefeated) justification.
} 


\section{References}

Audi, R. (2000). The Old Skepticism, the New Foundationalism, and Naturalized Epistemology. In E. Sosa, \& J. Kim (Eds.), Epistemology (pp. 325-335). Oxford: Blackwell Publishers.

Gettier, E. (1963). Is Justified True Belief Knowledge? Analysis, 23, 121-123. https:/doi.org/10.1093/analys/23.6.121

Kitcher, P. (1992). The Naturalists Return. The Philosophical Review, 101, 53-115. https:/doi.org/10.2307/2185044

Kripke, S. A. (2011). Philosophical Troubles. New York: Oxford University Press.

Lehrer, K. (2000). Theory of Knowledge (2nd ed.). Boulder, Colorado: Westview Press.

Macarthur, D. (2004). Naturalism and Skepticism. In M. de Caro, \& D. Macarthur (Eds.), Naturalism in Question (pp. 106-125). Cambridge: Harvard University Press.

Shope, R. K. (1983). The Analysis of Knowing. Princeton: Princeton University Press.

Stroud, B. (2011). Engagement and Metaphysical Dissatisfaction. New York: Oxford University Press. https:/doi.org/10.1093/acprof:oso/9780199764969.001.0001

Wittgenstein, L. (1953). Philosophical Investigations. Oxford: Oxford University Press.

Submit or recommend next manuscript to SCIRP and we will provide best service for you:

Accepting pre-submission inquiries through Email, Facebook, LinkedIn, Twitter, etc. A wide selection of journals (inclusive of 9 subjects, more than 200 journals)

Providing 24-hour high-quality service User-friendly online submission system

Fair and swift peer-review system Efficient typesetting and proofreading procedure

Display of the result of downloads and visits, as well as the number of cited articles Maximum dissemination of your research work

Submit your manuscript at: http://papersubmission.scirp.org/

Or contact ojpp@scirp.org 